\title{
Realizing innovative public waterworks: Aligning administrative capacities in collaborative innovation processes
}

Sanne Grotenbreg ${ }^{\mathrm{a}, *}$, Arwin van Buuren ${ }^{\mathrm{a}}$

aErasmus University Rotterdam, Department of Public Administration, Burgemeester Oudlaan 50, 3062 PA Rotterdam, The Netherlands

*Corresponding author. E-mail address: grotenbreg@fsw.eur.nl

Accepted for publication in the special volume 'Exploring the dynamics of water innovation' of the Journal of Cleaner Production. Please cite as: Grotenbreg, S., Van Buuren, A. (2016). 'Realizing innovative public waterworks: Aligning administrative capacities in collaborative innovation processes.' Journal of Cleaner Production (online first) http://dx.doi.org/10.1016/j.jclepro.2016.08.128

Keywords: Public-private innovation; Water sector innovation; Innovation policy; Administrative capacities; Public alignment; Regional industries

\section{Highlights}

- The way governments support innovation is changing

- Regionalization, public-private collaboration, customization are gaining importance

- Authorities must align their administrative capacities to support innovation

- Organizing interaction is an insufficient contribution to realize innovation

- Managing expectations of what governments can contribute is important 
ABSTRACT The importance of government support for innovation is widely acknowledged, but the way governments support innovation is changing. We discern three trends: local innovation policies are gaining importance; governments increasingly choose a bottom-up, tailor-made approach to support specific innovations; and there is more collaboration between public and private actors. We analyse these trends and investigate how modern governments employ their administrative capacities to support innovation. We conduct a comparative case study of four attempts to realize integrated energy and waterworks, combining water safety and sustainable energy generation. Despite broad support, attempts to realize such innovative, multifunctional works in The Netherlands have had varying degrees of success. We examine the governmental support for these attempts and assess how governments' actions affect the innovation process. We conclude that all governmental administrative capacities have to be employed, and that public alignment is crucial for a synchronized endeavour. We elucidate the growing importance and special role of local authorities in innovation and demonstrate how modern governments spur innovation with tailor-made support in close collaboration with the private sector. We further conclude that 'encouraging interaction' is an insufficient public contribution to innovation and that expectations must be carefully managed to avoid role confusion in publicprivate innovation. 


\section{Trends in governmental support for innovation}

It has become common practice to understand innovation as a result not solely of a private firm's research and technology activities (Smith, 2000), but also of the complex interaction between private producers, public policy, consumers, research and education, politics and infrastructure (Lundvall, 2010). The important role of governmental action in the generation, diffusion and adoption of innovation is widely acknowledged (Etzkowitz, 2003). This role is changing however. Different trends can be discerned in the way governments support innovation.

First, there is a gradual dispersal of innovation policy away from the national government towards regional and transnational (European) authorities, leading to a more multi-level setting (Partzsch, 2009: 986). Public research, technology and innovation are no longer exclusively in the hands of national authorities (Kuhlmann, 2001: 953). Reacting to the perceived failure of national governments to address environmental challenges, local governments are for example implementing their own policies to support innovation for sustainability, in a 'rebirth of regionalism' (Garret-Jones 2004: 3). The emergence of 'smart' cities is one example (Cohen and Amorós, 2014). Local governments are seeking to attract the creative class, establish innovation districts and profit from the job creation that innovation brings (Cohen and Amorós, 2014; Doh and Kim, 2014). The local environment is an important determinant of a private firm's capacity to innovate, and research shows that R\&D intensity and innovation activity vary more across regions than across national states (Oughton et al., 2002).

Related to this trend towards localization is the trend towards more applied, tailor-made governmental support for innovation. Increasingly, policy measures are developed in interaction with industry and universities (Etzkowitz and Klofsten, 2005). This results in 'smart regulation, a new type of negotiated settlement in which improved procedures allow for better, institutionally assured cooperation, more ambitious goals and limited administrative costs' (Partzsch, 2009: 985). Instead of 'sponsoring grand technology citadels', governments increasingly choose a more bottom-up approach, aimed at establishing local clusters, knowledge hubs and innovation districts (Garret-Jones, 2004: 3).

The third trend is the focus on collaborative governance and a more coordinating role for governments. Modern governments increasingly rely on collaboration to realize their policy goals. A host of non-governmental actors, public and private, are mobilized to solve today's 'wicked' public problems (Salamon, 2000; Klijn and Koppenjan, 2016). This also applies to the field of environmental innovation policymaking. Now that the state's capacity to deal with environmental challenges is diminishing, 'other actors and institutional arrangements are stepping in' (Francesch-Huidobro, 2015: 11). The role of the government in innovation processes shifts to 'encouraging interaction and cooperation between institutional spheres' (Lundberg, 2013: 213; Etzkowitz, 2003). A result of this trend towards collaborative governance is the blending of public and private innovation. Governments often involve private actors to address (traditionally) public problems. They try, for example, to increase private investments in innovation in the water sector (World Bank, 2004).

The vast literature on government support for innovation generally distinguishes between supply-oriented and demand-oriented policy instruments (Aschhoff and Wolfgang, 2009; Guerzoni and Raiteri, 2015). The former stimulate the supply side of innovation, for example by providing subsidies to private firms to support their R\&D activities. Demand-side instruments stimulate the market for innovative products and services, for example by public procurement or mandatory standards. Many studies test the effectiveness of a specific policy instrument for innovation, for example public procurement (Uyarra et al., 2014) or R\&D project subsidies (Kang and Park, 2012). Recently, growing 
attention has been given to the combined effect of various policy instruments (Rogge and Reichardt, 2013). The term policy mix is used to refer to the 'set of different and complementary policy instruments to address the problems identified' (Borrás and Edquist, 2013: 1514). The current literature, however, still focuses predominantly on traditional governmental support for innovation. There is a dearth of research exploring how local governments support innovation (Mazzarol et al., 2014) and, although innovation in the public and the private sector are melding, the literature on public and the literature on private innovation are still largely separated. There are, in other words, few studies that cover the new ways in which governments support innovation and the capacities they employ in doing this. Therefore we formulated the research question: What capacities are employed by public authorities to support public-private innovation and with what consequences?

To answer this question, we analyse four cases that reflect the trends in governmental support for innovation. We compare four regional projects in which public and private actors collaborate to add innovative techniques for sustainable energy generation (tidal energy, salinity gradient power) to public waterworks. Not only are these techniques innovative. Also the fact that public waterworks are used for commercial goals is novel, as is the way in which public and private actors have to collaborate to realize the implementation of the innovative techniques.

Transnational, national and local governments are involved in the projects, and their role differs per case. We unravel how the authorities contribute to the innovation processes by mobilizing different administrative capacities. We do not focus on the support of one sole government or policy instrument, but rather analyse the actual mix of different instruments and resources in a multi-level and multi-actor setting, thereby zooming in on a tailor-made form of governmental support for specific innovation projects. We investigate what extra activities authorities undertake to spur the adoption of innovations, in addition to the institutional framework of policies, rules and regulations at national level. Instead of comparing national systems, we thereby analyse variation within one such system to determine whether different mixes of employed capacities result into different outcomes. In section 2 , we further elaborate the public-private nature of integrated energy and waterworks and the special position of authorities in realizing them.

\section{Our research: integrated energy and waterworks as public-private innovation}

Innovation can be defined as 'the successful exploration of new ideas' (Francis and Bessant, 2005: 171) or, more elaborately, as 'the recognition of opportunities for profitable change and the pursuit of those opportunities all the way through to their adoption in practice' (Baumol, 2002). The technologies used in our cases, such as the turbines that generate tidal energy and the membranes for osmotic energy, are typical, private sector innovations developed by private firms for 'cost reduction, market expansion and profit maximization' (Schumpeter, 1934; Stoneman, 1983). These techniques are implemented, however, in public infrastructure, in dams, sluices, levees and dikes that normally are used only for flood risk safety and water management. As these waterworks are publically owned and managed, realizing integrated energy and waterworks thus inevitably has a public component. Such works could therefore be called public-private innovations.

In the water sector governmental support is of great importance to achieve innovation, because, compared to other sectors, the R\&D intensity and innovation rate is relatively low (Ipektsidis et al., 2014). Innovation in the water sector is driven predominantly by regulatory developments and social and environmental factors and much less by market demand and competitiveness (European Commission, 2014: 275 ). The relatively low profitability is one of the reasons for the lagging private 
investments in water innovation (World Bank, 2004). The same holds for the renewable energy sector; technology development for renewable power generation is largely driven by governmental support (Cantner et al., 2014).

To realize integrated energy \& waterworks besides the cooperation of public asset managers is essential. Their cooperation is not straightforward however, because the infrastructure used in energy and waterworks is vital for flood protection and the supply of fresh water. Dutch water management, anchored in laws and regulations, focuses on risk avoidance, and public asset managers have a strict, monofunctional task orientation (Van Buuren et al., 2013; Roovers and Van Buuren, 2014). It is therefore not easy to accommodate other functions at waterworks, as required in integrated energy and waterworks.

Governments generally promote innovation because it fosters economic growth (Smith, 2000: 75; Aschhoff and Wolfgang, 2009: 1235). Innovation is believed to increase competition, create jobs and generate wealth for individuals and the nation (Michael and Pearce, 2009: 285). These objectives also apply to governments' support for integrated energy and waterworks. In addition however, the realization of such works contributes to climate adaptation, sustainability and the transformation towards a green economy; and local governments hope that the innovative constructions will attract tourists and international businesses to their region.

The factors described combine into a complex position for authorities in the realization of integrated energy and waterworks. In our study, we take a closer look at this special position and investigate how authorities' contributions influence the attempts to realize such works. In section 3, we discuss the literature on the different capacities governmental actors can employ to support innovation.

\section{Administrative capacities to support innovation}

\subsection{Administrative capacities of the modern state}

There is a huge literature on organizations' capacities and capabilities. Most authors take a resourcebased view (Nelson and Winter, 1982), wherein institutional capacities are considered the core competences of organizations, built up over a long period of interaction and collaboration in which actors develop routines and competences that are essential for their joint effectiveness (Spekkink, 2013; Wehn de Montalvo and Alaerst, 2013). We focus solely on the level of government organizations and take a more instrumental view on capacities as the resources and instruments an organization uses to realize its ambitions.

To investigate the extra activities undertaken by governments to support the realization of integrated energy and waterworks, we use Lodge and Wegrich's (2014) theoretical framework on the administrative capacities of the modern state. Lodge and Wegrich's administrative capacities relate to the four principal governing resources: treasure, nodality, organization and authority (Hood, 1986; Howlett, 2000). In line with Lodge and Wegrich, we define administrative capacities as the sets of skills and competencies that authorities employ to address today's governance challenges, distinguishing between delivery capacity, analytical capacity, coordination capacity and regulatory capacity. In the rest of this section, we further define these four capacities and how they are used by authorities to support the adoption innovation. 


\subsection{Delivery capacity to support innovation}

Delivery capacity is an authority's capability to make things happen; it consists of the resources that governments use to perform their primary tasks at the policy frontline (Lodge and Wegrich, 2014). A state's delivery capacity relates to its treasure; it includes for example grants and loans and, in modern times, research funding (Hood, 1986; Howlett, 2000: 420). Government funding is an important stimulus for innovation (Guerzoni and Raiteri, 2015; Hyytinen and Toivanen, 2005). In collaborative innovation processes, access to resources is one of the fundamental conditions brought in by governmental actors (Sørensen and Torfing, 2012: 8). Authorities use their delivery capacity to spur innovation by providing 'funds, human resources (...) risk capital and base capital' (Moon and Bretschneider, 1997: 61). With their delivery capacity, they can support both the supply side of innovation, e.g. with R\&D subsidies, and the demand site, by purchasing innovative products in public procurement procedures (Caerteling et al., 2008; Cantner et al., 2014).

\subsection{Analytical capacity to support innovation}

Authorities' analytical capacity is based on the information that authorities have at their disposal and use to make policy choices; it is the knowledge that informs decision making. This form of capacity 'addresses demands on forecasting and intelligence that informs policy making under conditions of uncertainty' (Lodge and Wegrich, 2014: 14). Analytical capacity relates to the governing resource nodality and stems for example from the state's access to networks of expertise. Examples of nodalitybased policy instruments are advice and training, education and information provision (Hood, 1986; Howlett, 2000).

Governments can use their analytical capacity to support innovation by providing knowledge and information. This can be done in an indirect way by financing universities that generate knowledge spill-overs to the private market (Moon and Bretschneider, 1997; Aschhoff and Wolfgang, 2009: 1237) or in more direct ways by bringing data into innovation processes. In collaborative innovation, one of the roles of governmental actors is to bring 'new knowledge into play (...) and encourage transformative learning and out of the box thinking' (Sørensen and Torfing, 2012: 8). In the case of integrated energy and waterworks, access to governmental data on water streams and environmental conditions is essential for successful realization.

\subsection{Coordination capacity to support innovation}

Coordination capacity is the capacity to 'bring the necessary actors together to achieve problemsolving' (Lodge and Wegrich, 2014: 13). Besides being one of the participants in collaborative governance, government can act as the organizer or facilitator of the process, bringing participants together and 'aligning organisations from different backgrounds under often tricky conditions' (Lodge and Wegrich, 2014: 13). Salamon (2000: 1638) speaks of the 'new government's orchestration skills'. In modern times, governments do not 'play all the instruments alone' and they cannot depend on 'control and demand'; instead, they use their coordination capacity to enable the orchestra's performance.

In innovation the government's role as network manager, boundary spanner, broker and intermediary is also gaining importance (Gregersen, 1992; Howells, 2006; Partzsch, 2009). Modern governments promote innovation by encouraging interaction among institutional spheres (Lundberg, 
2013: 213; Etzkowitz, 2003). Authorities have to 'create, institutionalize, and manage open and flexible arenas for collaborative interaction with other relevant and affected actors' to make innovation possible (Sørensen and Torfing, 2011: 16; Nambisan, 2008).

\subsection{Regulatory capacity to support innovation}

Regulatory capacity (Lodge and Wegrich, 2014: 11) is the modern state's capacity to prohibit or permit and refers to the government's power to constrain economic and social activities. Regulatory capacity is based on the governing resource, authority; associated policy instruments are regulations and licences, and in modern states, labelling, treaties and political agreements (Hood, 1986; Howlett, 2000: 420).

Authorities can use their regulatory capacity to spur innovation by adding, improving or removing regulation (Gregersen, 1992; Aschhoff and Wolfgang, 2009; Cohen and Amorós, 2014). The literature on innovation often identifies rules and regulations as a hindrance to innovation (Sørensen and Torfing, 2012). One function of regulations is to eliminate risk, whereas the acceptance of risk is a precondition for innovation (Brown and Osborne, 2013). Rules can, however, also be necessary to make innovation possible. In the case of integrated energy and waterworks, there is on the one hand an overload of rules; there are many, often conflicting, laws and regulations concerning water safety, energy generation and nature conservation. On the other hand however, there is an institutional vacuum, there are no rules yet specifically aimed at integrated energy and waterworks. Governments can thus stimulate innovation by using their regulatory capacity to abolish or adjust rules or draft new ones, for example in the form of new 'organizational or juridical arrangement, additional contracts, temporary permissions or bilateral agreements or new policy rules' (Van Buuren et al., 2013: 694).

\section{Methodology}

\subsection{Case selection}

The cases selected are The New Afsluitdijk, Tidal Power Plant Brouwersdam, Oosterscheldekering and Testing Centre Grevelingendam. As stated, these cases were selected because they display the three trends in governmental support for innovation discerned from the literature. The technologies used, the membranes and tidal turbines, are private sector innovations. Their implementation in public waterworks, that are essential for flood protection and are managed by water authorities with a monofunctional task orientation, is as much as an innovation however. We can learn much from these cases because they can be considered as most extreme cases in water innovation (Seawright and Gerring, 2008). On the one hand, there is a strong shared belief that the Dutch have to invest in their world-leading position with regard to innovative delta technology. Both the national government (with innovation policies aimed at stimulating innovation in a couple of top sectors, including water) and the regional authorities emphasize the importance of making the Dutch Delta the worldwide window of innovative delta solutions. At the same time - as elaborated in section 2 - the collaboration of the responsible water authority is indispensable to realize this kind of innovation because it necessitates the use of public waterworks. That makes these cases very relevant from this article's perspective, as these innovation processes necessitate the employment of different administrative capacities by various public actors with different and even conflicting interests. 
The national authorities involved are the same in all four cases and the other authorities involved have comparable capacities. Although the resources and administrative capacities that could be employed by the authorities thus do not differ significantly, the capacities that they employ in reality do differ. The cases further differ with regard to their (tentative) success, making them suitable for exploring the relation between administrative capacities employed and innovation success. Much research on innovation is biased towards best practices; by selecting cases with different levels of success we avoid this (Borins, 2001).

Because of our research design, our results cannot be directly generalized to all processes of (water) innovation. Innovation processes all have 'their own dynamisms and are influenced by, among other things, the features of technologies, the specific organizational and institutional settings, legal frameworks etc.' (Meijer, 2014: 206). Although our research does not lead to generalized empirical knowledge, it does enhance our understanding of the role of public authorities in water innovations and leads to a detailed understanding of the relation between the capacities they employ and the success of innovations. Our case studies thus can contribute to further theory development on this topic (Walton, 1992).

\subsection{Data collection}

We gathered data by in-depth semi-structured interviews, document analysis and observations. We studied relevant documents such as newspaper articles, governmental policy briefs and notes, agreements between actors, permit and subsidy applications and allocations. This document analysis was used to reconstruct the planning process, the relevant actions of involved actors and their formal agenda. We attended several public meetings where stake- and shareholders discussed specific issues concerning the projects (such as the business case or the contract arrangement).

Between February and December 2014, we conducted 17 interviews. We also made use of the transcripts of 23 more interviews conducted by master students writing their theses. The interviews were equally distributed among the cases. We interviewed all key players in the four cases: public professionals of national and local authorities, directors of the private firms involved and representatives from other public organizations. The interviews were used to deepen our understanding of the process and the agenda of the actors involved, the perception of the authorities' contribution to that process and actors' perceptions about the relative impact of this contribution. Finally, our reconstruction of capacities and their impact was checked by one key representative per case (in all cases a public policy official).

\subsection{Operationalization and measurement}

On the basis of the literature on administrative capacities and innovation policy, we constructed Table 1 containing possible public contributions to energy and waterworks. We use this table to determine the capacities employed by the public authorities in our cases. 
Table 1. Possible governmental support for integrated energy and waterworks ordered by administrative capacities

\begin{tabular}{|l|l|l|}
\hline $\begin{array}{l}\text { Administrative } \\
\text { capacity }\end{array}$ & Government support for innovation & Indicators. Authorities' actions \\
\hline $\begin{array}{l}\text { Delivery } \\
\text { capacity }\end{array}$ & $\begin{array}{l}\text { Financial support, subsidy and } \\
\text { funding schemes, risk and base } \\
\text { capital, R\&D support, public } \\
\text { procurement, organizational and } \\
\text { human resources }\end{array}$ & $\begin{array}{l}\text {-provide R\&D subsidies, grants or research } \\
\text { funding } \\
\text {-act as launching customer } \\
\text {-stand surety for loan } \\
\text {-adjust assets for multifunctional use }\end{array}$ \\
\hline $\begin{array}{l}\text { Analytical } \\
\text { capacity }\end{array}$ & $\begin{array}{l}\text { Information provision, advice, } \\
\text { training, public networks of expertise, } \\
\text { policy analyses, cost-benefit and } \\
\text { impact analyses, open data }\end{array}$ & $\begin{array}{l}\text {-commission studies } \\
\text {-share public information and expertise } \\
\text {-supply information for permit application } \\
\text {-support subsidy or grant application } \\
\text {-investigate possibilities for innovation }\end{array}$ \\
\hline $\begin{array}{l}\text { Coordination } \\
\text { capacity }\end{array}$ & $\begin{array}{l}\text { Network management, bringing } \\
\text { actors together, boundary spanning, } \\
\text { initiating and maintaining } \\
\text { intermediary platforms }\end{array}$ & $\begin{array}{l}\text {-organize workshops and meetings } \\
\text {-involve relevant actors } \\
\text {-maintain relations with actors involved } \\
\text {-negotiate and lobby } \\
\text {-ease entrance to organization for private } \\
\text { initiators (e.g. by 1 single window) } \\
\text {-synchronize actions and collaborate with } \\
\text { other authorities involved }\end{array}$ \\
\hline $\begin{array}{l}\text { Regulatory } \\
\text { capacity }\end{array}$ & $\begin{array}{l}\text { Constrain economic and social } \\
\text { activities, prohibit and permit via } \\
\text { regulations and licences, labelling, } \\
\text { treaties, political agreements }\end{array}$ & $\begin{array}{l}\text {-abolish, adjust and/or develop policy, rules } \\
\text { and regulations to support innovation } \\
\text {-sign agreements } \\
\text {-give (temporary) permissions, accept risks }\end{array}$ \\
\hline
\end{tabular}

To assess the extent to which these capacities are actually employed, we make a distinction between low, medium or high use, which we define as follows.

- Low: Almost no elements of this type of capacity are employed;

- Medium: Various elements of this type of capacity are employed;

- High: (Almost) all different elements of this type of capacity are employed.

We are interested in the effect of the capacities employed on the success of the attempt to realize energy and waterworks. We acknowledge that success is subjective, difficult to define and hard to assess, even more so because the attempts in our study are ongoing. We define success as the realization of an integrated energy and waterworks and we take into account interim results, such as permits granted, subsidies obtained or construction started. These are milestones on the way to full realization. We distinguish between four aspects of success: (perceived) progress, feasibility, institutional fit and legitimacy. We define feasibility as the availability of (financial) resources to realize the innovative works, and progress as the satisfaction of the involved actors about how fast the project is proceeding. Institutional fit stands for the fit of the project within the institutional framework and organizational values of public authorities involved, and legitimacy is the support the project receives from authorities, other stakeholders and the general public.

\section{Case description: four attempts to realize integrated energy and waterworks}

In this section, we briefly summarize the four attempts to realize integrated energy and waterworks in The Netherlands. Table 2 gives an overview of the main characteristics of the cases, followed by a 
narrative description of the stimulus, the involved actors' interests, and dependences and progress in all four cases.

Table 2. Main characteristics of the cases

\begin{tabular}{|c|c|c|c|c|}
\hline & The New Afsluitdijk & $\begin{array}{l}\text { Tidal Power Plant } \\
\text { Brouwersdam }\end{array}$ & Oosterscheldekering & $\begin{array}{l}\text { Testing Centre } \\
\text { Grevelingendam }\end{array}$ \\
\hline Water work & $\begin{array}{l}32 \mathrm{~km} \text { long dam, } \\
\text { north Netherlands }\end{array}$ & $\begin{array}{l}6.5 \mathrm{~km} \text { long dam, } \\
\text { southwest } \\
\text { Netherlands }\end{array}$ & $\begin{array}{l}8 \mathrm{~km} \text { storm surge } \\
\text { barrier, southwest } \\
\text { Netherlands }\end{array}$ & $\begin{array}{l}6 \mathrm{~km} \text { long inland } \\
\text { dam, southwest } \\
\text { Netherlands }\end{array}$ \\
\hline $\begin{array}{l}\text { Project } \\
\text { content }\end{array}$ & $\begin{array}{l}15-25 \text { turbines in } 8- \\
12 \text { shafts + blue } \\
\text { energy pilot } \\
\text { installation }\end{array}$ & $\begin{array}{l}\text { Large number of } \\
\text { turbines in } 100 \\
\text { metre-long breach in } \\
\text { dam }\end{array}$ & $\begin{array}{l}3-5 \text { turbines in 1-2 } \\
\text { shafts }\end{array}$ & $\begin{array}{l}\text { Test location for tidal } \\
\text { turbines }\end{array}$ \\
\hline $\begin{array}{l}\text { Estimated } \\
\text { power }\end{array}$ & $\sim 2-3 \mathrm{MW}^{*}$ & $\sim 5-45 \mathrm{MW}$ & $\sim 1 \mathrm{MW}$ & Varying \\
\hline $\begin{array}{l}\text { Estimated } \\
\text { costs for } \\
\text { realization }\end{array}$ & $\sim € 20-25 \mathrm{~m}^{*}$ & $\sim € 60-250 \mathrm{~m}^{* *}$ & $\sim € 9 \mathrm{~m}$ & $\sim € 10-30 \mathrm{~m}$ \\
\hline Stimulus & $\begin{array}{l}\text { Renovation dam for } \\
\text { water safety }\end{array}$ & $\begin{array}{l}\text { Breach in dam for } \\
\text { water quality }\end{array}$ & $\begin{array}{l}\text { Need for turbine } \\
\text { showcase }\end{array}$ & $\begin{array}{l}\text { Reopening sluice for } \\
\text { water quality }\end{array}$ \\
\hline Initiator & $\begin{array}{l}\text { Private actors and } \\
\text { local governments }\end{array}$ & $\begin{array}{l}\text { National and local } \\
\text { governments }\end{array}$ & Private actors & Local governments \\
\hline $\begin{array}{l}\text { Asset } \\
\text { manager }\end{array}$ & $\begin{array}{l}\text { Focuses on } \\
\text { renovation, } \\
\text { facilitates private } \\
\text { initiatives }\end{array}$ & $\begin{array}{l}\text { Actively investigates } \\
\text { possibilities of power } \\
\text { plant }\end{array}$ & $\begin{array}{l}\text { Facilitates private } \\
\text { initiatives }\end{array}$ & $\begin{array}{l}\text { Invests in reopening } \\
\text { sluice }\end{array}$ \\
\hline $\begin{array}{l}\text { Local } \\
\text { governments }\end{array}$ & $\begin{array}{l}\text { Support private } \\
\text { initiatives }\end{array}$ & $\begin{array}{l}\text { Act alongside } \\
\text { national asset } \\
\text { manager }\end{array}$ & $\begin{array}{l}\text { Support private } \\
\text { initiatives }\end{array}$ & $\begin{array}{l}\text { Initiated, aims to } \\
\text { facilitate private } \\
\text { initiative }\end{array}$ \\
\hline Private actors & Initiated projects & $\begin{array}{l}\text { Participate in market } \\
\text { consultation }\end{array}$ & Initiated projects & $\begin{array}{l}\text { Some take initiative, } \\
\text { some wait-and-see }\end{array}$ \\
\hline $\begin{array}{l}\text { Public- } \\
\text { private } \\
\text { collaboration }\end{array}$ & $\begin{array}{l}\text { Local governments } \\
\text { support, national } \\
\text { government } \\
\text { facilitates private } \\
\text { initiative }\end{array}$ & $\begin{array}{l}\text { Market consultation, } \\
\text { private actors wait- } \\
\text { and-see }\end{array}$ & $\begin{array}{l}\text { Local governments } \\
\text { support, national } \\
\text { government } \\
\text { facilitates private } \\
\text { initiative }\end{array}$ & $\begin{array}{l}\text { Governments want } \\
\text { to facilitate, private } \\
\text { actors wait-and-see }\end{array}$ \\
\hline Drivers & $\begin{array}{l}\text { Ambition and } \\
\text { support local } \\
\text { governments }\end{array}$ & $\begin{array}{l}\text { Broad-mindedness } \\
\text { asset manager }\end{array}$ & $\begin{array}{l}\text { Public subsidy, } \\
\text { support local } \\
\text { governments }\end{array}$ & $\begin{array}{l}\text { Perseverance public } \\
\text { and private initiators }\end{array}$ \\
\hline Barriers & $\begin{array}{l}\text { Energy projects small } \\
\text { re renovation, no } \\
\text { integration }\end{array}$ & $\begin{array}{l}\text { High costs, } \\
\text { dependence on } \\
\text { other local } \\
\text { developments }\end{array}$ & No private investors & $\begin{array}{l}\text { Little interest from } \\
\text { private investors and } \\
\text { costumers }\end{array}$ \\
\hline $\begin{array}{l}\text { Progress } \\
\text { (August 2016) }\end{array}$ & $\begin{array}{l}\text { Tender renovation, } 2 \\
\text { energy projects } \\
\text { realized, } 1 \text { working } \\
\text { on business case }\end{array}$ & $\begin{array}{l}\text { Market consultation } \\
\text { closed, tender in } \\
\text { preparation }\end{array}$ & $\begin{array}{l}1 \text { of } 2 \text { initiated } \\
\text { projects realized }\end{array}$ & $\begin{array}{l}\text { Private consortium } \\
\text { works on business } \\
\text { case and permits }\end{array}$ \\
\hline
\end{tabular}

*Tidal energy Den Oever, tidal energy Kornwerderzand and blue energy together

**Additional costs for tidal plant in breach, range for different options 


\subsection{The New Afsluitdijk}

The Afsluitdijk (Enclosure Dam) was constructed in 1927-1933; the dam is essential for water safety, and the adjacent lake is an important source of fresh water. The dam no longer meets the safety criteria and needs extensive renovation. The asset manager, the national Department of Waterways and Public Works (Rijkswaterstaat, RWS) is in charge of this renovation. The national government decided to focus solely on water safety and finance only essential renovation. Complementary ambitions, e.g. in relation to nature development, tourism and sustainable energy generation, are left to local authorities and private actors. For them, the complementary plans are very important because it is believed that they will generate a much needed boost to the local economy.

Local governments and private firms therefore hope to seize the opportunity of the renovation to realize and expand pilot installations for sustainable energy generation. The asset owner, the Ministry of Infrastructure and Environment, has a somewhat ambiguous attitude towards the energy projects. It prescribes (and solely pays for) essential renovation but, at the same time, the minister is enthusiastic about the Afsluitdijk becoming an integrated energy and waterworks. Therefore, RWS feels unofficially obliged to support the local ambitions and has agreed to help the private actors and local authorities to implement their plans.

Since 2008, a turbine constructor has been operating a pilot installation in one of the shafts of an outlet sluice. In 2015, partly financed by public subsidies, the firm expanded its installation with three more turbines. Together with the local authorities, it wants to realize a second pilot installation. There have been talks with different possible investors and participants, but to date (August 2016) without success. In 2014, another private firm opened a pilot installation for the generation of blue energy, using the difference in salinity between fresh and salt water, at the Afsluitdijk. Realizing the installation was a shared ambition of the local authorities, and the firm received subsidies from national and local authorities.

\subsection{Tidal Power Plant Brouwersdam}

The Brouwersdam, constructed in 1971, encloses a saltwater inlet of the North Sea, creating the lake Grevelingenmeer. Since the enclosure, the water oxygen level has gone down, damaging nature and the local economy. Therefore, the public authorities developed plans to breach the Brouwersdam to restore estuarine dynamics and improve the water quality in the Grevelingenmeer. With this plan, the idea emerged to realize a tidal power plant in the breach. The authorities hoped that the alteration to the dam, a very costly undertaking, could be financed with the revenues from energy generation. In 2013, local authorities and RWS set up a project bureau to investigate the feasibility of a power plant in the Brouwersdam. They conducted an extensive market consultation and joint fact-finding with market actors to investigate different options and costs. They concluded that it was not possible to finance the renovation with the revenues from energy generation; rather, the realization of a power plant would entail additional costs.

The local authorities nevertheless see great benefits in the realization of a power plant. They expect great benefits for local employment, the knowledge economy and attracting visitors to the region. They have small budgets, however, and are willing nor able to make large financial investments in a power plant. RWS advocates for a power plant but is also unable to make extensive financial contributions. RWS is now (August 2016) preparing a concession-based tender in which the realization and the exploitation of the power plant are combined. The private actors in this case have a somewhat 
wait-and-see attitude. They consider the power plant a public ambition and hope to be given the job to build the plant at public expense.

\subsection{Oosterscheldekering}

The Oosterscheldekering (Eastern Scheldt storm surge barrier) is part of the delta works in the southwest of The Netherlands, built after a flood in 1953 as protection from the North Sea. In 2008, a consultancy firm and a turbine constructor both took the initiative to install tidal turbines in one of the breaches in the dam. Their primary goal is to create a showcase for potential customers. Both firms applied to RWS for a permit and for several local, national and European subsidies. The Province of Zeeland is an enthusiastic advocate and promoter of tidal energy. The region is known worldwide for its innovative delta works. Zeeland now hopes to update this status by combining the waterworks with sustainable energy generation. The Province expects many financial and social spin-offs for the region. RWS aims to contribute to the multifunctional use of infrastructure, sustainability and technology development. Therefore, RWS decided to deliberate jointly with the firms and help them to formulate a viable permit application. In an intensive, collaborative process, the private firms and RWS came to an agreement about the terms and conditions under which the firms could install their installations and generate energy at the dam. Both projects received several public subsidies but had a hard time finding additional private investors. Consequently, the project was postponed multiple times. The two initiatives merged, and in September 2015 the turbine constructor and partners successfully realized one of the projects by installing five turbines in one of the dam's breaches. It is uncertain whether it will also realize the second project. In 2016 the firm applied for an additional $€ 2 \mathrm{~m}$ in subsidies to expand the project.

\subsection{Testing Centre Grevelingendam}

The Grevelingendam is a $6 \mathrm{~km}$ long dam in the southwest of The Netherlands, built in 1958 as part of the delta works. The Grevelingendam is not a primary flood defence and its water safety function is no longer clear. The dam has a road connection and several recreational functions. Because the water quality in the adjacent lake, the Grevelingenmeer, is low since its enclosure, plans were developed to reopen the sluice in the dam to restore estuarine dynamics in the lake. With this plan to reopen the sluice, the idea emerged to realize a testing centre for tidal turbines in the sluice. The local authorities see great benefits in establishing a testing centre. The region aims to become 'the home of the tidal energy industry', and a testing centre would contribute to this ambition. They are unwilling, however, to realize (and finance) such a centre themselves. The Province of Zeeland therefore took the initiative to find private initiators. It funded engineering and a consultancy firm to organize a series of workshops to bring together interested actors. The local authorities hoped that private firms and knowledge institutes would unite in these workshops to realize the test location without governmental participation, but the workshops did not have the hoped-for result. One obstacle is that it is unclear whether there is any need for a test location on the private market. The asset owner, the Ministry of Infrastructure and Environment, is willing to reopen the sluice earlier than planned to facilitate the realization of a tidal testing centre. The work has been put out to tender, and the reopening of the sluice is planned in 2017. The consultancy firm formed a consortium of private partners that is now (August 2016) trying to obtain the necessary permits and public and private funding. 


\section{Analysis}

We now take a closer look at the public authorities' contributions to the four attempts to realize the integrated energy and waterworks. We categorize the capacities used and indicate to what element of the innovation processes (feasibility, progress, institutional fit or legitimacy) the authorities contributed (see Tables 3-10).

\subsection{The administrative capacities employed per case}

\subsubsection{The New Afsluitdijk}

Table 3. Public authorities' contributions to innovation process The New Afsluitdijk

\begin{tabular}{|c|c|c|c|}
\hline $\begin{array}{l}\text { Public } \\
\text { authority }\end{array}$ & $\begin{array}{l}\text { Authorities' action contributing to energy and } \\
\text { waterworks }\end{array}$ & $\begin{array}{l}\text { Administrative } \\
\text { capacity }\end{array}$ & $\begin{array}{l}\text { Positively } \\
\text { contributed to }\end{array}$ \\
\hline $\begin{array}{l}\text { Ministry } \\
\text { Economic } \\
\text { Affairs }\end{array}$ & Subsidy for projects, per amount of energy generated & Delivery & Feasibility \\
\hline $\begin{array}{l}\text { Ministry } \\
\text { I\&M }\end{array}$ & $\begin{array}{l}€ 20 \mathrm{~m} \text { (total) financial contribution to local sustainability } \\
\text { projects }\end{array}$ & Delivery & Feasibility \\
\hline \multirow{7}{*}{$\begin{array}{l}\text { Asset } \\
\text { manager } \\
\text { RWS }\end{array}$} & $\begin{array}{l}\text { Established } 1 \text { single window for all requests from the } \\
\text { region }\end{array}$ & Coordination & $\begin{array}{l}\text { Progress, } \\
\text { institutional fit }\end{array}$ \\
\hline & Participates in multiple local deliberative bodies & Coordination & Progress \\
\hline & $\begin{array}{l}\text { Supported private initiators to formulate admissible } \\
\text { permit application }\end{array}$ & Analytical & Institutional fit \\
\hline & $\begin{array}{l}\text { Negotiated with private initiators about permit } \\
\text { requirements and adjusted standard requirements }\end{array}$ & Regulatory & Institutional fit \\
\hline & $\begin{array}{l}\text { Informed local actors about its own activities, advised } \\
\text { local actors about theirs }\end{array}$ & Coordination & $\begin{array}{l}\text { Progress, } \\
\text { institutional fit }\end{array}$ \\
\hline & $\begin{array}{l}\text { Offered opportunity to include local projects in tender for } \\
\text { renovation }\end{array}$ & Coordination & $\begin{array}{l}\text { Progress, } \\
\text { institutional fit }\end{array}$ \\
\hline & $\begin{array}{l}\text { Obliges the renovation contractor to take into account the } \\
\text { local project plans }\end{array}$ & Regulatory & Institutional fit \\
\hline \multirow{7}{*}{$\begin{array}{l}\text { Local } \\
\text { authorities } \\
\text { (united in } \\
\text { project } \\
\text { bureau) }\end{array}$} & $\begin{array}{l}\text { Support private project initiators in finding financial } \\
\text { investors }\end{array}$ & Coordination & $\begin{array}{l}\text { Progress, } \\
\text { feasibility }\end{array}$ \\
\hline & $\begin{array}{l}\text { Support private projects initiators to formulate admissible } \\
\text { subsidy applications }\end{array}$ & Analytical & $\begin{array}{l}\text { Institutional fit, } \\
\text { feasibility }\end{array}$ \\
\hline & $\begin{array}{l}\text { Lobbied asset manager to purchase generated energy } \\
\text { directly from initiators }\end{array}$ & Coordination & Feasibility \\
\hline & Contributed financially to projects through local funds & Delivery & Feasibility \\
\hline & $\begin{array}{l}\text { Stand surety/pre-finance projects, thereby taking financial } \\
\text { risks }\end{array}$ & Delivery & Progress \\
\hline & $\begin{array}{l}\text { Negotiated with asset manager about conditions for } \\
\text { including projects in renovation tender }\end{array}$ & Coordination & $\begin{array}{l}\text { Progress, } \\
\text { institutional fit }\end{array}$ \\
\hline & Secure coherence/relation between individual projects & Coordination & Progress \\
\hline
\end{tabular}

In The New Afsluitdijk case, the local authorities employ a wide range of administrative capacities to contribute to the sustainable energy projects (see table 3). The effectiveness of their effort, however, often proves insufficient. The innovation process is very time-consuming, and the realization of the various projects is uncertain. To a certain extent, there is public alignment between the different authorities involved; the national asset manager and the local authorities have regular contact and keep one another informed about their activities, but they fail to synchronize their activities in such a 
way that the implementation of the local agenda is connected to the national government's renovation work. Furthermore, despite requests from the local authorities, RWS is not willing to complement the capacities that the local authorities lack. These include, for example, more delivery capacity (in the form of directly purchasing the generated electricity) and regulatory capacity. An important barrier is the fact that RWS is not willing to adjust its rules with regard to the planning or the scope of the dam renovation. Table 4 gives an overview of the administrative capacities employed by the different authorities involved.

Table 4. Overview of administrative capacities employed in The New Afsluitdijk case

\begin{tabular}{|l|l|l|l|l|}
\hline & $\begin{array}{l}\text { Delivery } \\
\text { capacity }\end{array}$ & $\begin{array}{l}\text { Analytical } \\
\text { capacity }\end{array}$ & $\begin{array}{l}\text { Coordination } \\
\text { capacity }\end{array}$ & $\begin{array}{l}\text { Regulatory } \\
\text { capacity }\end{array}$ \\
\hline EU/national government & Medium & Low & Low & Low \\
\hline National asset manager & Low & Medium & Medium & Medium \\
\hline Local authorities & Medium & Medium & Medium & Low \\
\hline
\end{tabular}

\subsubsection{Tidal Power Plant Brouwersdam}

Table 5. Public authorities' contributions to innovation process Tidal Power Plant Brouwersdam

\begin{tabular}{|c|c|c|c|}
\hline $\begin{array}{l}\text { Public } \\
\text { authority }\end{array}$ & $\begin{array}{l}\text { Authorities' action contributing to energy and } \\
\text { waterworks }\end{array}$ & $\begin{array}{l}\text { Administrative } \\
\text { capacity }\end{array}$ & $\begin{array}{l}\text { Positively } \\
\text { contributed to }\end{array}$ \\
\hline \multirow[t]{3}{*}{$\begin{array}{l}\text { Asset } \\
\text { manager RWS }\end{array}$} & $\begin{array}{l}\text { Entered collaboration with local authorities, became } \\
\text { member of project bureau }\end{array}$ & Coordination & $\begin{array}{l}\text { Progress, } \\
\text { legitimacy }\end{array}$ \\
\hline & $\begin{array}{l}\text { Will give initiators the chance to realize an energy } \\
\text { plant in waterworks }\end{array}$ & $\begin{array}{l}\text { Regulatory, } \\
\text { delivery }\end{array}$ & Institutional fit \\
\hline & $\begin{array}{l}\text { Prepared innovative integrated tender for realization } \\
\text { and exploitation of power plant }\end{array}$ & Regulatory & Feasibility \\
\hline \multirow{4}{*}{$\begin{array}{l}\text { Local } \\
\text { governments } \\
\text { (united in } \\
\text { project } \\
\text { bureau) }\end{array}$} & $\begin{array}{l}\text { Researched financial, technical and social feasibility } \\
\text { and affordability of different power plants }\end{array}$ & Analytical & $\begin{array}{l}\text { Feasibility, } \\
\text { institutional fit, } \\
\text { progress }\end{array}$ \\
\hline & $\begin{array}{l}\text { Organized meetings with potential stake- and } \\
\text { shareholders }\end{array}$ & Coordination & Legitimacy \\
\hline & $\begin{array}{l}\text { Conducted market consultation, joint fact-finding } \\
\text { and red flag analysis }\end{array}$ & Analytical & $\begin{array}{l}\text { Institutional fit, } \\
\text { progress }\end{array}$ \\
\hline & $\begin{array}{l}\text { Lobbied Ministry of Economic Affairs to financially } \\
\text { contribute }\end{array}$ & Coordination & Feasibility \\
\hline \multirow{2}{*}{$\begin{array}{l}\text { Province Zuid- } \\
\text { Holland }\end{array}$} & Suggested the idea of a power plant & Coordination & Progress \\
\hline & $\begin{array}{l}\text { Set realization of power plant as condition for } \\
\text { financial contribution to renovation for water quality }\end{array}$ & Coordination & $\begin{array}{l}\text { Progress, } \\
\text { feasibility }\end{array}$ \\
\hline $\begin{array}{l}\text { Province } \\
\text { Zeeland }\end{array}$ & Willing to contribute financially to power plant & Delivery & Feasibility \\
\hline
\end{tabular}

In this case, there has been great public alignment. RWS and the local authorities, united in a project bureau, employed a lot of analytical and coordination capacity researching the possibilities and feasibility of a power plant (see table 5). The authorities worked closely with private actors, and the employment of their administrative capacities has been fine-tuned in order to fit the private ambitions. It is too early to conclude whether the authorities' effort will be successful; the exploration of the feasibility of a tidal energy plant is ongoing. Currently (August 2016), RWS is exploring how it can employ its coordination and regulatory capacity with an innovative, integrated tender in which the realization and the exploitation of the power plant are combined. Much effort is being made to align what the public authorities can further contribute to realization, but it is uncertain whether the 
necessary public funds will become available. The employment of delivery capacity in the form of a substantial public financial contribution will be essential for realization but it is uncertain if this becomes available. Table 6 gives an overview of the administrative capacities employed in this case.

Table 6. Overview of administrative capacities employed in the Tidal Power Plant Brouwersdam case

\begin{tabular}{|l|l|l|l|l|}
\hline & $\begin{array}{l}\text { Delivery } \\
\text { capacity }\end{array}$ & $\begin{array}{l}\text { Analytical } \\
\text { capacity }\end{array}$ & $\begin{array}{l}\text { Coordination } \\
\text { capacity }\end{array}$ & $\begin{array}{l}\text { Regulatory } \\
\text { capacity }\end{array}$ \\
\hline National asset manager & Low & High & High & Medium \\
\hline Local authorities & Low & High & High & Low \\
\hline
\end{tabular}

\subsubsection{Oosterscheldekering}

Table 7. Public authorities' contributions to innovation process Oosterscheldekering

\begin{tabular}{|c|c|c|c|}
\hline $\begin{array}{l}\text { Public } \\
\text { authority }\end{array}$ & $\begin{array}{l}\text { Authorities' action contributing to energy and } \\
\text { waterworks }\end{array}$ & $\begin{array}{l}\text { Administrative } \\
\text { capacity }\end{array}$ & $\begin{array}{l}\text { Positively } \\
\text { contributed to }\end{array}$ \\
\hline EU & $€ 3,250,000$ subsidy for regional development & Delivery & Feasibility \\
\hline \multirow{2}{*}{$\begin{array}{l}\text { Ministry } \\
\text { Economic } \\
\text { Affairs }\end{array}$} & $€ 1,750,000$ subsidy & Delivery & Feasibility \\
\hline & Subsidy, per amount of energy generated & Delivery & Feasibility \\
\hline $\begin{array}{l}\text { Ministry } \\
\text { I\&M }\end{array}$ & $\begin{array}{l}\text { Gave RWS permission to support the privately initiated } \\
\text { projects }\end{array}$ & Delivery & Institutional fit \\
\hline \multirow{8}{*}{$\begin{array}{l}\text { Asset } \\
\text { manager } \\
\text { RWS }\end{array}$} & $\begin{array}{l}\text { Actively investigated possibilities for privately initiated } \\
\text { projects }\end{array}$ & Analytical & Institutional fit \\
\hline & Supplied information necessary for permit application & Analytical & $\begin{array}{l}\text { Progress, } \\
\text { institutional fit }\end{array}$ \\
\hline & $\begin{array}{l}\text { Had monthly talks with initiators, helped them to } \\
\text { formulate admissible permit application }\end{array}$ & Analytical & Institutional fit \\
\hline & $\begin{array}{l}\text { Negotiated with initiators about permit requirements } \\
\text { and adjusted standard requirements }\end{array}$ & Regulatory & $\begin{array}{l}\text { Progress, } \\
\text { institutional fit }\end{array}$ \\
\hline & $\begin{array}{l}\text { Extended standard permit period to improve private } \\
\text { business case }\end{array}$ & Regulatory & Feasibility \\
\hline & $\begin{array}{l}\text { Granted a provisional permit before all necessary } \\
\text { research was conducted }\end{array}$ & Regulatory & $\begin{array}{l}\text { Progress, } \\
\text { feasibility }\end{array}$ \\
\hline & $\begin{array}{l}\text { Accepted (financial and safety) risk of damage to the } \\
\text { waterworks }\end{array}$ & Regulatory & Institutional fit \\
\hline & $\begin{array}{l}\text { Extended monitoring programme for new infrastructure } \\
\text { (costs for private initiator) }\end{array}$ & Regulatory & Institutional fit \\
\hline \multirow{3}{*}{$\begin{array}{l}\text { Province } \\
\text { Zeeland }\end{array}$} & $€ 500,000$ subsidy & Delivery & Feasibility \\
\hline & $\begin{array}{l}\text { Compensated potential objectors to prevent notice of } \\
\text { objection procedure }\end{array}$ & Coordination & $\begin{array}{l}\text { Legitimacy, } \\
\text { progress }\end{array}$ \\
\hline & Lobbied other authorities to support the initiatives & Coordination & Legitimacy \\
\hline
\end{tabular}

Table 7 contains all the public contributions made to the Oosterscheldekering project. In this case, there was effective alignment between the public authorities involved; Table 8 shows that together they employed all four capacities. RWS employed its analytical and regulatory capacity in a very explorative mode, deliberating with the initiators and adjusting its permitting rules. The Province of Zeeland acted as network manager and applied a lot of coordination capacity to achieve public alignment and broad public support. Zeeland closely monitored the barriers in the innovation process, employed the capacities that were missing and removed obstacles for the private initiators. All levels of government employed their delivery capacity; this resulted in large subsidies. This case is therefore 
relatively successful: in September 2015 one of the two privately initiated projects was realized; five tidal turbines have been installed in the dam.

Table 8. Overview of administrative capacities employed in the Oosterscheldekering case

\begin{tabular}{|l|l|l|l|l|}
\hline & $\begin{array}{l}\text { Delivery } \\
\text { capacity }\end{array}$ & $\begin{array}{l}\text { Analytical } \\
\text { capacity }\end{array}$ & $\begin{array}{l}\text { Coordination } \\
\text { capacity }\end{array}$ & $\begin{array}{l}\text { Regulatory } \\
\text { capacity }\end{array}$ \\
\hline EU/national government & High & Low & Low & Low \\
\hline National asset manager & Low & High & Low & High \\
\hline Local authorities & High & Low & High & Low \\
\hline
\end{tabular}

\subsubsection{Testing Centre Grevelingendam}

Table 9. Public authorities' contributions to innovation process Testing Centre Grevelingendam

\begin{tabular}{|l|l|l|l|}
\hline $\begin{array}{l}\text { Public } \\
\text { authority }\end{array}$ & Authorities' action contributing to energy and waterworks & $\begin{array}{l}\text { Administrative } \\
\text { capacity }\end{array}$ & $\begin{array}{l}\text { Positively } \\
\text { contributed to }\end{array}$ \\
\hline $\begin{array}{l}\text { Asset } \\
\text { manager } \\
\text { RWS }\end{array}$ & $\begin{array}{l}\text { Renovated and reopened sluice to make testing centre } \\
\text { possible (estimated costs } € 8,300,000, \text { commissioned by } \\
\text { Ministry I\&M). }\end{array}$ & Delivery & Institutional fit \\
\hline $\begin{array}{l}\text { Province } \\
\text { Zeeland }\end{array}$ & Searched for private initiators & Coordination & $\begin{array}{l}\text { Legitimacy, } \\
\text { progress }\end{array}$ \\
\cline { 2 - 4 } & Paid $€ 100,000$ to draw up programme of requirements & $\begin{array}{l}\text { Delivery, } \\
\text { analytical }\end{array}$ & $\begin{array}{l}\text { Institutional fit, } \\
\text { progress }\end{array}$ \\
\cline { 2 - 4 } & $\begin{array}{l}\text { Made testing centre part of EU research project, paid for } \\
\text { workshops to support realization of the test centre }\end{array}$ & $\begin{array}{l}\text { Delivery, } \\
\text { coordination }\end{array}$ & $\begin{array}{l}\text { Legitimacy, } \\
\text { progress }\end{array}$ \\
\cline { 2 - 4 } & $\begin{array}{l}\text { Financed } € 100,000 \text { revolving fund for private initiators to } \\
\text { start up project }\end{array}$ & Delivery & $\begin{array}{l}\text { Feasibility, } \\
\text { progress }\end{array}$ \\
\hline
\end{tabular}

In this case, the local authorities, especially the Province of Zeeland, employed a lot of coordination capacity (see table 9), thereby hoping to bring together private actors who then together would take the initiative to realize a testing centre, but the sole employment of coordination capacity proved an insufficient public contribution. Only after substantial financial support is a private consortium now making an attempt to realize a testing centre. RWS has limited its contribution to renovating and reopening the sluice. It has not been necessary to employ regulatory capacity because there have been no permit applications yet. Table 10 gives an overview of the administrative capacities employed in this case.

Table 10. Overview of administrative capacities employed in the Testing Centre Grevelingendam case

\begin{tabular}{|l|l|l|l|l|}
\hline & Delivery capacity & $\begin{array}{l}\text { Analytical } \\
\text { capacity }\end{array}$ & $\begin{array}{l}\text { Coordination } \\
\text { capacity }\end{array}$ & $\begin{array}{l}\text { Regulatory } \\
\text { capacity }\end{array}$ \\
\hline National asset manager & Medium & Low & Low & Low \\
\hline Local authorities & Medium & Low & High & Low \\
\hline
\end{tabular}

\subsection{Case comparison}

Table 11 gives an overview of the capacities employed and the success of the four cases. To date (August 2016), the Oosterscheldekering case is the most successful; one of the two initiated projects has been realized. In this case, all administrative capacities have been employed. Several authorities have made substantial financial contributions, and the province employed a lot of coordination 
capacity to ensure public alignment and broad support. The asset manager employed its analytical and regulatory capacity to support the private initiatives. In the other cases, one or more of these success factors are missing, resulting in moderate to no success (yet).

Table 11. Comparison of the administrative capacities employed in the four cases

\begin{tabular}{|l|l|l|l|l|l|}
\hline & $\begin{array}{l}\text { Delivery } \\
\text { capacity }\end{array}$ & $\begin{array}{l}\text { Analytical } \\
\text { capacity }\end{array}$ & $\begin{array}{l}\text { Coordination } \\
\text { capacity }\end{array}$ & $\begin{array}{l}\text { Regulatory } \\
\text { capacity }\end{array}$ & Success \\
\hline $\begin{array}{l}\text { The New } \\
\text { Afsluitdijk }\end{array}$ & Medium & Medium & Medium & Medium & $\begin{array}{l}\text { Moderately successful, all } \\
\text { capacities employed, little } \\
\text { public alignment, } \\
\text { insufficient feasibility, } \\
\text { moderate institutional fit }\end{array}$ \\
\hline $\begin{array}{l}\text { Tidal Power Plant } \\
\text { Brouwersdam }\end{array}$ & Low & High & High & Medium & $\begin{array}{l}\text { Relatively promising, low } \\
\text { feasibility, slow but steady } \\
\text { progress, moderate } \\
\text { institutional fit, high } \\
\text { legitimacy }\end{array}$ \\
\hline $\begin{array}{l}\text { Oosterschelde- } \\
\text { kering }\end{array}$ & High & High & High & High & $\begin{array}{l}\text { Successful, high feasibility, } \\
\text { slow but steady progress, } \\
\text { moderate institutional fit, } \\
\text { high legitimacy. }\end{array}$ \\
\hline $\begin{array}{l}\text { Testing Centre } \\
\text { Grevelingendam }\end{array}$ & Medium & Low & High & $\begin{array}{l}\text { Moderate success, low } \\
\text { feasibility, slow progress, } \\
\text { moderate institutional fit, } \\
\text { high legitimacy. }\end{array}$ \\
\hline
\end{tabular}

\subsubsection{Delivery capacity in the innovation process}

The employment of delivery capacity, in the form of financial contributions, is an important stimulus for innovation (Guerzoni and Raiteri, 2015; Hyytinen and Toivanen, 2005); our cases confirm this. Public funding is, at least at the current stage of technology development, essential to realize integrated energy and waterworks. The availability of a large subsidy was a driver of success in the Oosterscheldekering case, and the absence of public funding is an important barrier in the other cases. Allowing public infrastructure to be used by external actors is another, essential form of employing delivery capacity to enable this public-private innovation. The financial contributions made by the authorities in our cases are all one-time contributions. Governments are hesitant to make long-term investments and become partners in these projects. Neither are they willing to act as launching customers to support the demand side of this innovation (Gregersen, 1992; Aschhoff and Wolfgang, 2009). The Oosterscheldekering case shows that this does not necessarily have to be a problem; the works can successfully be initiated, owned and run by private actors. This, however, must be clear from the beginning of the innovation process. In the Grevelingendam case, public authorities incessantly expressed their ambition for a testing centre. This left the private actors in a wait-and-see position; they expected the public authorities to take the lead and supply the necessary resources. The authorities' failure to do so led to deadlock.

\subsubsection{Analytical capacity in the innovation process}

In the Oosterscheldekering case, the asset manager's willingness to share governmental data on water streams and environmental conditions with the private initiators and pro-actively deliberate jointly 
about the possibilities was an important success factor. In The New Afsluitdijk, the asset manager is more hesitant to share information and work together with the private initiators. In the Brouwersdam case, the asset manager and the regional authorities not only shared information, but also went a step further by conducting research to generate new information from which private partners in the innovation process could benefit.

\subsubsection{Coordination capacity in the innovation process}

Our analysis illustrates that the role of the government as network manager and boundary spanner in innovation is essential (Etzkowitz, 2003; Howells, 2006; Partzsch, 2009). To realize integrated energy and waterworks, the authorities' coordination capacity proved especially important to ensure public alignment and shared ambitions. For the Tidal Power Plant Brouwersdam, the national and local authorities worked closely together in a project bureau, and this led to broad support. In the Afsluitdijk case, the lack of alignment between national and local authorities is a barrier to success. Innovation processes benefit from public authorities that work together, know one another's capacities and are willing to step in when others cannot deliver. Coordination capacity is also important to involve possible share- and stakeholders, keep track of the process and eliminate possible obstacles, as the Province of Zeeland did in the Oosterscheldekering and Grevelingendam cases. The Grevelingendam case, however, also shows that the sole employment of coordination capacity, bringing relevant actors together and facilitating their collaboration, is an insufficient public contribution to realize innovation.

\subsubsection{Regulatory capacity in the innovation process}

The initiators of integrated energy and waterworks have to work with different legal frameworks concerning water safety, energy generation, technology development and regional development. Besides the rules and regulations, dominant values such as efficiency, effectiveness and risk aversion can form a barrier to innovation. To realize integrated energy and waterworks, organizational fit has to be created between the dominant institutional framework and the aimed-for innovations (Van Buuren et al., 2013). To do this, public authorities have to employ their regulatory capacity to abolish or adjust existing rules and draw up new ones (Gregersen, 1992; Moon and Bretschneider, 1997; Aschhoff and Wolfgang, 2009). However, in our cases, this capacity is hardly employed. To realize energy and waterworks, customization of organizational rules and tailor-made agreements are essential. As with the employment of analytical capacity, it is important that public authorities use their regulatory capacity in a positive, open and learning way. Only when the asset manager is willing to collaborate with initiators and exchange wishes and ideas is it possible to come to arrangements that safeguard public values and enable innovation. This is in line with the literature on innovation, which states that regulation created in interaction with relevant actors leads to 'a negotiated settlement of smart regulation' (Partzsch, 2009: 985; Lundberg, 2013).

Because of the low number of cases, it is not possible to discern clear patterns in the various capacity mixes and related success rates. In all four cases however, it proved crucial for the authorities to be able to combine their capacities in such a way that an optimal mix was formed that enabled realization of the innovations. The national asset manager had an important role in organizing the formal opportunity, providing access to the infrastructure and supplying the necessary information about on-site physical conditions. The local authorities provided the necessary network facilities and could give access to the (much needed) public funds. The Oosterscheldekering case shows how the 
asset manager and local authorities align their efforts and together successfully support the realization of an innovation. The national asset owner and the Ministry of Economic Affairs, however, are nearly absent in the cases. This is unfortunate, as the first has the regulatory capacity essential for multifunctional use of public infrastructure and the latter has the delivery capacity crucial to enable this kind of innovation. The aloofness of these two authorities makes it difficult for the other actors to achieve successful innovation, as they have to deal with quite restrictive conditions.

\section{Conclusion}

The importance of governmental support for innovation is widely acknowledged. In the water sector, the involvement of authorities in the innovation process is of even greater importance (Krozer et al, 2010). The way governments support innovation is changing however. Local innovation policies are gaining importance (Cohen and Amorós, 2014); governments increasingly choose a bottom-up, tailormade approach to support specific innovations (Garret-Jones, 2004); and public and private actors collaborate more, leading to a blend of public and private sector innovation (Francesch-Huidobro, 2015). We analyse these trends and investigate how modern governments employ their administrative capacities to support innovation by adjusting their own routines and by facilitating private actors to implement their innovative techniques.

Our study shows the combined effect of various policy mixes (Borrás and Edquist, 2013). For complex, public-private innovations such as integrated energy and waterworks to succeed, no single policy instrument can do the job. The authorities have to employ all their capacities: regulatory capacity to adjust their own policies and regulations; delivery capacity for to enhance the feasibility of implementing techniques currently not fully developed; analytical capacity to provide the necessary information about possible consequences and impacts; and coordination capacity to reach public alignment and build a strong public-private coalition. The four capacities, however, do not have to be employed by one and the same public actor; ideally, authorities complement one another. The authorities all employ their capacities in a way that fits their own procedures and ambitions, but public alignment is crucial. Public-private innovation necessitates the synchronized deployment of authorities' capacities in a contextualized, dedicated way because each situation is unique (even when the same technological innovation is pursued). The framework of Lodge and Wegrich (2014) can help authorities to make an inventory of the available and the necessary administrative capacities.

Our analysis confirms the growing importance and special role of local authorities in innovation support (Kuhlmann, 2001). Local authorities foresee great benefits of innovation for their region and develop tailor-made support for regional innovative industries (Doh and Kim, 2014). Local authorities' capacities are limited, but they are an important actor in the innovation process. With their coordination capacity, they act as network managers, bringing together relevant share- and stakeholders, achieving public alignment and public support. They work in close collaboration with private project initiators, keep track of potential barriers and smooth the innovation process.

Our study shows the extra activities that modern governments can undertake to spur innovation, in addition to the existing national framework of policies, rules and regulations. The authorities employ their capacities to support specific innovation projects. Through interaction and negotiation, public and private partners achieve tailor-made solutions and successful public-private innovation in these projects. Our study further shows how the government's role as pacer in innovation, 'encouraging interaction and cooperation between institutional spheres' (Lundberg, 2013: 213), works out in practice. Bringing the relevant actors together and subsequently facilitating their 
collaboration are tasks that modern governments are very keen to undertake. We find, however, that often this is too small a public contribution for innovation to succeed. A substantial financial contribution, for example, is often needed.

Our study demonstrates another pitfall of collaborative public-private innovation. Authorities tend to express great ambitions, even when they do not intend to take a prominent role in the innovation process or to act as launching customer. Deadlock can occur when articulated public ambitions do not match their actual ability or willingness to act. When authorities are trying to activate the private sector with their enthusiasm and support and arrange a series of interactions, they can unintentionally accomplish the opposite: a wait-and-see private sector that expects the government to take the lead. To avoid this role confusion, managing expectations is crucial. There has to be clarity about actors' aspirations, the capacities they are willing to employ and their expectations of other, public and private, actors. Integrated energy and waterworks are realized under challenging conditions. In general, public-private collaboration for innovation is a sensitive process, an ongoing search in which the actors involved continuously have to exchange wishes and opportunities to reach solutions that are acceptable for all.

Funding: This study is executed as part the research project Energising deltas, funded by the European Regional Development Fund (ERDF), Opportunities for West and co-financed by the Province of NoordHolland.

\section{References}

Aschhoff, B., Wolfgang, S., 2009. Innovation on demand - Can public procurement drive market success of innovations? Research Policy 38, pp. 1235-1247.

Baumol, W.J., 2002. The Free-Market Innovation Machine: Analyzing the Growth Miracle of Capitalism, Princeton University Press, Woodstock, Oxon.

Borins, S., 2001. Innovation, Success and Failure in Public Management Research: Some Methodological Reflections. Public Management Review. 3:1, 3-17.

Borrás, S., Edquist, C., 2013. The choice of innovation policy instruments. Technol. Forecast. Soc. Change 80, 1513-1522.

Brown, L., Osborne, S.P., 2013. Risk and Innovation. Public Management Review. 15(2), 186-208. doi:10.1080/14719037.2012.707681

Caerteling, J.S., Halman, J.I.M., Dorée, A.G., 2008. Technology Commercialization in Road Infrastructure: How Government Affects the Variation and Appropriability of Technology. J PROD INNOV MANAG 2008; 25: 143-161

Cantner, U., Graf, H., Herrmann, J., Kalthaus, M., 2014. Inventor networks in renewable energies: The influence of the policy mix in Germany. Jena Economic Research Papers, No. 2014-034. http://pubdb.wiwi.uni-jena.de/pdf/wp_2014_034.pdf 
Cohen, B., Amorós, J.E., 2014. Municipal demand-side policy tools and the strategic management of technology life cycles. Technovation 34, 797-806

Doh, S., Kim, B., 2014. Government support for SME innovations in the regional industries: The case of government financial support program in South Korea. Research Policy 43, 1557-1569

Etzkowitz, H., 2003. Innovation in innovation: the triple helix of university-industry-government relations. Social Science Information, 42:3, pp. 293-337.

Etzkowitz, H., Klofsten, M., 2005. The innovating region: toward a theory of knowledge based regional development. R\&D Management, 35:3, pp. 243-255.

European Commission, 2014. 2013-Innovation Union Competitiveness Report. Directorate General Research and Innovation, European Commission, Brussels.

Francesch-Huidobro, M., 2015. Collaborative governance and environmental authority for adaptive flood risk: recreating sustainable coastal cities. Journal of Cleaner Production, 17, pp. 568-580.

Francis, D., Bessant, J., 2005. Targeting innovation and implications for capability development. Technovation 25, pp. 171-183.

Garret-Jones, S., 2004. From citadels to clusters: the evolution of regional innovation policies in Australia. R\&D Management 34, 1, 2004

Gregersen, B., 1992. The public sector as a pacer in national systems of innovation, in: Lundvall, B.A., (Eds.), National systems of innovation: Towards a theory of innovation and interactive learning. Pinter Publishers, London, pp. 133-151.

Guerzoni, M., Raiteri, E., 2015. Demand-side vs. supply-side technology policies: Hidden treatment and new empirical evidence on the policy mix. Research Policy 44, pp. 726-747.

Hood, C., 1986. The Tools of Government. Chatham House Publishers, London.

Howells, J., 2006. Intermediation and the role of intermediaries in innovation. Research Policy 35, 715728.

Howlett, M., 2000. Managing the "hollow state": procedural policy instruments and modern governance. Canadian Public Administration. 43: 4, 412-431.

Hyytinen, A., Toivanen, O., 2005. Do financial constraints hold back innovation and growth?: Evidence on the role of public policy. Research Policy. 34(9), 1385-1403.

Ipektsidis, B, Remotti, L., Rumpf, G., Spanos, Y. E., Vonortas, N., Montalvo, C., Bulavskaya, T., Dröes, M., Moghayer, S. M., Koops, O., 2014. R\&D and Innovation performance in the Collection, purification and distribution of water sector. RTD Sectors, Work Package 2 Sector report. 
Kang, K., Park, H., 2012. Influence of government R\&D support and inter-firm collaborations on innovation in Korean biotechnology SMEs. Technovation 32, 68-78

Klijn, E.H., Koppenjan, J.F.M., 2016. Governance networks in the public sector. Oxon: Routledge.

Krozer, Y., Hophmayer-Tokich, S., Van Meerendonk, H., Tijsma, S., Vos, E., 2010. Innovations in the water chain - experiences in the Netherlands. J. Clean. Prod. 18, 439-446.

Kuhlmann, S., 2001. Future governance of innovation policy in Europe - three scenarios. Research Policy 30, pp. 953-976.

Lodge, M., Wegrich, K., 2014. Introduction: Governance Innovation, Administrative Capacities, and Policy Instruments, in: Lodge, M., Wegrich, K. (Eds.), The Problem-solving Capacity of the Modern State. Oxford University Press, Oxford, pp. 16-26.

Lundberg, H., 2013. Triple Helix in practice: the key role of boundary spanners. European Journal of Innovation Management, 16 (2), 211-226.

Lundvall, B.-Å., 2010. National innovation systems of innovation, towards a theory of innovation and interactive learning. Anthem Press, London.

Mazzarol, T., Clark, D., Reboud, S., Gough, N., Olson, P., 2014. Perceptions of innovation climate and the influence of others: a multi-country study of SMEs. International Journal of Innovation Management Vol. 18, No. 1. doi: 10.1142/S1363919614500091

Meijer, A.J., 2014. From Hero-Innovators to Distributed Heroism: An in-depth analysis of the role of individuals in public sector innovation. Public Management Review, 16:2, 199-216. doi: 10.1080/14719037.2013.806575

Michael, S.C., Pearce II, J.A., 2009. The need for innovation as a rationale for government involvement in entrepreneurship. Entrepreneurship \& Regional Development: An International Journal, 21:3, pp. 285-302, doi: 10.1080/08985620802279999.

Moon, M.J., Bretschneider, S., 1997. Can State Government Actions Affect Innovation and Its Diffusion?: An Extended Communication Model and Empirical Test. Technological Forecasting and Social Change, 54 57-77.

Nambisan, S., 2008. Transforming government through collaborative innovation. Harvard Kennedy School of Government, Washington, DC.

Nelson, R., Winter, S., 1982. An Evolutionary Theory of Economic Change. Harvard University Press, Cambridge, MA. 
Oughton, C., Landabaso, M., Morgan, K. 2002. The regional innovation paradox: innovation policy and industrial policy. Journal of Technology Transfer, 27:1, pp. 97-110.

Partzsch, L., 2009. Smart regulation for water innovation - the case of decentralized rainwater technology. J. Clean. Prod. 17 (11), 985-991.

Rogge, K., Reichardt, K., 2013. Towards a Comprehensive Policy Mix Conceptualization for Environmental Technological Change: A Literature Synthesis. Working Paper, No. S3/2013, Available at: www.econstor.eu

Roovers, G., Van Buuren, M.W., 2014. Van investeren naar evolueren: Wat eigentijds asset management betekent voor de organisatie van het waterbeheer. Water Governance, 04/2014, 27-33.

Salamon, L.M., 2000. The New Governance and the Tools of Public Action: An Introduction. Fordham Urban Law Journal, 28:5, 1611-1674.

Schumpeter, J.A., 1934. The theory of economic development: An inquiry into profits, capital, credit, interest, and the business cycle. Transaction Publishers, Piscataway, New Jersey.

Seawright, J., Gerring, J., 2008. Case selection techniques in case study research: a menu of qualitative and quantitative options. Political Research Quarterly, 61(2), pp. 294-308.

Smith, K., 2000. Innovation as a Systemic Phenomenon: Rethinking the Role of Policy. Enterprise \& Innovation Management Studies, 1:1, pp. 73-102.

Sørensen, E., Torfing, J., 2011. Enhancing collaborative innovation in the public sector. Administration and Society, 43(8): 842-68.

Sørensen, E., Torfing, J., 2012. Introduction Collaborative Innovation in the Public Sector. The Innovation Journal: The Public Sector Innovation Journal, 17(1), 1-14.

Spekkink, W.A.H., 2013. Institutional capacity building for industrial symbiosis in the Canal Zone of Zeeland in the Netherlands: a process analysis. Journal of Cleaner Production, 52, pp. 342-355.

Stoneman, P., 1983. The economic analysis of technological change. Oxford University Press, Oxford.

Uyarra, E., Edler, J., Garcia-Estevez, J., Georghiou, L., Yeow, J., 2014. Barriers to innovation through public procurement: A supplier perspective. Technovation 34, 631-645

Van Buuren, A., Eshuis, J., Bressers, N., 2013. The Governance of Innovation in Dutch Regional Water Management: Organizing fit between organizational values and innovative concepts. Public Management Review, 17:5, 679-697. doi: 10.1080/14719037.2013.841457

Walton, J., 1992. Making the theoretical case. In Ragin, C.C., Becker, H.S., (Eds.), What is a case? Exploring the foundations of social inquiry, pp. 121-137. Cambridge, UK: Cambridge University Press. 
Wehn de Montalvo, U., Alaerts, G., 2013. Leadership in knowledge and capacity development in the water sector: a status review, editorial introduction to the special issue. Water Policy 15 (Suppl. 2), 114.

World Bank, 2004. Water resources sector strategy. World Bank, Washington DC. 